\title{
Quaternary glacial records in mountain regions: A formal stratigraphical approach
}

\author{
1 Geography, School of Environment and Development, Mansfield Cooper Building, The University of Manchester, Oxford Road, Manchester \\ M13 9PL, United Kingdom. \\ 2 Godwin Institute of Quaternary Research, Department of Geography, Downing Place, University of Cambridge, Cambridge CB2 3EN, United \\ Kingdom.
}

\begin{abstract}
Glacial deposits in locally-glaciated mountain regions are often expressed through their surface form and the study of these deposits constitutes a major branch of geomorphology. Studies of glacial depositional records in mountain areas have often neglected formal stratigraphical procedure resulting in an ad hoc development of quasi-stratigraphical nomenclature. Here, a formal stratigraphical procedure is recommended, since this enables a systematic approach to the subdivision of glacial deposits in mountain regions. Moreover, such an approach facilitates, in some instances, the development of a formal chronostratigraphy that can be compared to regional and global geological time scales. This is important in locally-glaciated mountain regions where glacial deposits represent one of the most important records of cold stage environments. Given that glacial landforms represent a key component of the Quaternary record, maintaining a formal link between geomorphological and geological stratigraphical procedure is a fundamental requirement of a consistent and comparable stratigraphical framework.
\end{abstract}

\section{Introduction}

The aim of this paper is to advocate a formal procedure for the subdivision of Quaternary glacial sedimentary units in locally-glaciated mountain regions. Through this, glacial sequences can be compared and used in conjunction with other terrestrial sequences to establish regional chronostratigraphical frameworks. This process promotes the development of independent and coherent stratigraphical frameworks for terrestrial sedimentary sequences from which comparisons can be made with sequences spanning equivalent intervals in the marine and ice sheet records.

Throughout geology, stratigraphy is the universal means by which rock strata are classified and divided. It may seem almost superfluous to make this statement, yet in mountain environments stratigraphy has often been less important for the vast majority of workers than the description of landforms and their lateral relationships.

To most geologists, mountains would seem unlikely places in which meaningful Quaternary sedimentary sequences might be found, since in broad terms they are zones of net erosion with steep slopes and highly active process regimes where sediments are unlikely to accumulate to any great extent. The vast majority of upland mountain environments, particularly those in the middle and high latitudes have been shaped by glaciation during the last 2 mil- lion years of the Quaternary Period, especially during the Pleistocene Epoch. In spite of the predominance of intense polycyclic, coldclimate erosion in these areas, the majority of glaciated mountains include not only erosional landforms such as cirques and troughs but also depositional accumulations, including moraines and other deposits of glacial origin.

Glaciers also formed in many mid- and low latitude mountain ranges during the cold stages of the Pleistocene, since snowlines were depressed to much lower altitudes than today (Ehlers and Gibbard, 2004a, 2004b, 2004c). Important palaeoclimatic records can be preserved where these glaciers formed and decayed, as well as in periglacial areas where landforms and sediments formed as a result of cold temperatures in non-glacial areas. Moreover, many glaciated mountain massifs occur outside regions that would have supported extensive ice sheets at low latitudes, such as those in the Mediterranean, the Himalaya, the northern Andes, the southern Rockies and equatorial East Africa. Establishing the occurrence, timing and controlling factors of glaciation is extremely important in order to better understand regional patterns of the global climate through the Quaternary.

Stratigraphy is the organisation of rock or sediment strata into successions of units and is key to understanding the environmental record in sedimentary sequences. This applies as much to the glacial record in mountain regions as to any other sedimentary sequences. Lithostratigraphical units are the basic units of geological mapping and are bodies of rocks, which are defined and characterised on the basis of their lithological properties and their stratigraphical relations. In mountain regions that have experienced glacial activity, sediment-landform morphology and morphostratigraphical position are also important in establishing the sedimentary sequence. In fact, the latter may be more important in differentiating between different stratigraphical units since glacial units that originated under multiple glaciations in the same area may be indistinguishable on the basis of lithology alone. Therefore, in mountain regions a morpho-lithostratigraphical approach is required to unravel and order glacial sequences.

The ordering of depositional units based on morpho-lithostratigraphy in individual cirque-valley systems is the first step towards the wider establishment of regional stratigraphical relationships and must precede any attempts to establish the position of these units in time. The correlation of sequences at different places on the Earth's surface is fundamental to geology and is the foundation of the stratigraphical method (e. g. Gibbard and West, 2000). Successful correlation between different sequences requires rigorous and precise standards. In modern stratigraphical studies, precise standards to which other records can be compared are provided by chronostratigraphy: the classification of rock strata into units representing intervals of geological time (Bowen, 1978; Salvador, 1994). Quaternary sequences are commonly subdivided on the basis of climate changes and for many Quaternary workers, climato- and chronostratigraphical units are interchangeable. This situation is unsatisfactory because of the imprecision it may bring to inter-regional and ultimately global correlation (Bowen, 1978; Gibbard and West, 2000). It is therefore preferable to develop a formally-defined, chronostrati- 
graphically-based system that is fully compatible with that for the rest of the geological column, supported wherever possible by a reliable geochronology. Since climate change is used as the basis for chronostratigraphy in the Quaternary, and because climate change is represented differently under terrestrial and marine conditions, it is also necessary that terrestrial and marine successions are clearly separated (cf. Gibbard and West, 2000). It is this premise that underlies the importance of developing independent regional chronostratigraphical frameworks and this concept applies equally to different geographical regions on the Earth's continents.

In many glaciated mountain areas, the principal approach employed in the study of former glacial activity is geomorphological, since surface features, such as moraines, are key to former glacier delimitation. A geomorphological approach inherently employs morphostratigraphy to subdivide glacial deposits and associated landforms. However, it can be argued that this currently condemns the geomorphological approach to the sidelines of Quaternary stratigraphy and inhibits the use of glacial units in formal chronostratigraphy. This is because: a) morphostratigraphical units are usually only given informal stratigraphical status (Richmond, 1959; Rawson et al., 2002) and; b) most geomorphological studies do not adhere to formal stratigraphical procedure. The latter is likely to stem from the former. This paper aims to redress this disunion and proposes a means by which formal stratigraphical procedure and nomenclature can be applied to glacial (and periglacial) sequences in mountain regions outside those of the former large Pleistocene ice sheets.

\section{Current approaches to glacial stratigraphy in mountain regions}

Most studies of mountain glaciation employ geomorphological criteria to identify and subdivide glacial sedimentary units. However, the schemes and terminology employed to describe and organise subdivided glacial sequences are often not applied consistently. Richmond and Fullerton (1986) noted that a profusion of formal and informal stratigraphical names had developed in different regions of North America. Here, workers sometimes apply an allostratigraphical approach to mountain glacial sequences based on discontinuities in the stratigraphical record (NASCN, 1983). Elsewhere, most workers apply a traditional morphostratigraphical approach. However, in all areas there is often little emphasis given to formal stratigraphical procedure. This is the case for both the subdivision and ordering of sedimentary units independent of time (allo-, litho- and morphostratigraphy) and more especially, when relating glacial sequences in geological time (chronostratigraphy).

The need for a rigorous stratigraphical approach is discussed by Osmaston (1989a) and Owen et al. (1998) for the Himalaya. These authors recognised that the low level of understanding of the glacial sequence in this region resulted partly from poor adherence to strict stratigraphical procedures and they advocated a series of measures to improve the situation. These measures included:

a) the establishment of distinct glacial 'stages' based on features (i.e. landforms) that are unequivocally glacial in origin;

b) that glacial 'stages' should be clearly separated spatially, stratigraphically and sedimentologically;

c) that differentiation of glacial 'stages' should be demonstrated through clear differences in age, based on absolute dating or relative weathering;

d) that stages should relate to type sites only;

e) that attempts to correlate and to extend the use of stage names between regions must be avoided until absolute chronologies have been established;

f) that 'stages' should not be accorded the status of full glacials, stadials, climatic optima or glacial maxima based on marine isotope stratigraphies or the Northern Hemisphere ice sheets, until absolute chronologies have been established (Owen et al., 1998).
These proposals are clearly useful as a means of subdividing glacial deposits and most of the recommendations are supported here. However, few workers use stratigraphical terminology compatible with formal stratigraphies established elsewhere based on the application of international stratigraphical procedures (cf. Hedberg 1976; Salvador, 1994). For example, in the Himalayan review of Owen et al. (1998), the term 'stage' is not used in a formal chronostratigraphical sense, since it is used to refer to discrete glacier advances recorded in moraine assemblages. A chronostratigraphical unit, such as the stage, is defined as a body of rocks or sediments that includes all rocks or sediments formed during a specific interval of geological time, and only those rocks formed during that time span (Salvador, 1994). Thus, if glacial deposits were laid down on multiple occasions during the last glacial stage then all of these deposits should be considered as a single chronostratigraphical unit. This is especially important since stage units should ideally be directly chronostratigraphically comparable, i.e. to the Würmian, Weichselian and Wisconsian Stages of the Alps, Northern Europe and North America respectively - the main objective being to place sediment and rock units within a globally-applicable standard timescale.

The issue of the use of the term 'stage' outlined above is not merely one of semantics. It highlights the concept of events in the stratigraphical record and event stratigraphy, whereby geologically short-lived events, of up to several thousand years or more duration, leave some trace in the rock record, such as moraines for example (Whittaker et al., 1991; Rawson et al., 2002). The recognition of glacial events based on moraines is widely used to define glacial phases in locally-glaciated mountain regions and examples include those described in Owen et al. (1998) in the Himalaya as well that of Shanahan and Zreda (2000) and Osmaston (1989b, 2002) in East Africa, and Clapperton et al. (1995) in South America.

The identification of glacial events clearly provides important insight into an otherwise fragmented record. However, this approach on its own does not establish a stratigraphical framework inclusive of glacier oscillations through time. Whilst the latter are clearly recognised in work by authors such as Clapperton et al. (1995), the identification of short-lived glacial events does not provide a basis for comparison with glacial chronostratigraphical units over wide areas. This is especially the case since glacier advances are likely to be spatially asynchronous. If true chronostratigraphical units are to be established for these contexts, it is vital that stratigraphical nomenclature is consistent with that for sediments and rocks throughout geological time and with that used in lowland and extraglacial regions. Without such an approach, meaningful comparison with other terrestrial chronostratigraphies and independent reference to a standard time-scale is difficult to achieve.

\section{A formal stratigraphical approach - theory}

In order to systematically establish the sedimentary sequence in any locally-glaciated mountain area, a formal stratigraphical approach can be adopted. Lithostratigraphical units are the basic units of geological mapping that conform to the Law of Superposition. In glaciated cirque-valley systems, lithostratigraphy is usually applied in conjunction with morphostratigraphy and the establishment of an integrated morpho-lithostratigraphy is described below.

Each formal lithostratigraphical unit should have a clear and precise definition or characterisation. A type section or a type locality is an essential requisite to all lithologically-identified units. Salvador (1994, p.26) defined type sections as 'a specific interval or point in a specific sequence of rock strata and constitutes the standard for the definition and characterisation of the stratigraphic unit being defined'. However, in the context of localised glacial deposits in mountain areas, the sequence of rock or sediment strata is often expressed through the spatial surface morphology, i.e. moraine mounds and ridges, and sections are often limited in vertical extent. 
In these circumstances, the sediment can be regarded as massive and non-layered and thus a type locality can provide the reference point for the definition of the deposits in the area. As in all geological sequences, the type locality is 'the specific geographic locality in which the type section is situated' (Salvador, 1994, p. 26) and provides the fundamental building-block for local stratigraphy.

A particular type section or type locality may be defined by the lithological characteristics of the sediment. Lithostratigraphical units should be defined and distinguished on the basis of sediment properties such as dominant lithology, sorting, clast size, shape, roundness, and so on. It is important that non-genetic terms are used, such as diamicton rather than till, since some sediment materials may be incorrectly interpreted, with colluvial deposits perhaps mis-interpreted as till, for example. Moreover, soil development may be an important characteristic of certain deposits and pedostratigraphical units, defined as 'a buried, three-dimensional body of rock that consists of one or more pedological horizons' (NASCN, 1983, p.864) may be useful as a marker horizon when applied in conjunction with the lithostratigraphy.

In mountain areas, which have experienced localised valley and cirque glaciation, geomorphology is commonly a key characteristic in defining a type section or type locality. For example, sections may have been cut in well-defined and possibly arcuate ridges. Ridge freshness may also be a distinctive characteristic, with 'freshness' being defined here as the morphological clarity of landforms, as expressed by ridge amplitude and sharpness, indicating limited post-depositional modification - although this is a difficult attribute to quantify. Rawson et al. (2002) suggested that the identification of a sediment body based on surface form, or morphostratigraphy, is not comparable to standard lithological units. However, it is often the case in glaciated cirque-valley systems, that definition on strict litho- and morphological grounds is virtually identical or at least strongly overlapping. Moreover, the International Commission on Stratigraphy (2004) stated that both geological and geomorphological characteristics can be applied in the description of a type section. Application of this principle would imply that some cirque moraine ridges, for example, may be described (in non-genetic terms) as arcuate ridges dominated by subrounded boulders with this morphological description also constituting a lithological description.

In all cases, it is the combination of landform and sediment that is the key to interpreting the nature of formerly glaciated upland systems (Benn and Evans, 1998, ch. 11). The usual bases of stratigraphical position are often expressed in the lateral, rather than the vertical plane. This is because it is virtually always the case that the lowermost moraines will be older than those that lie inside and up-valley from them, since glacier advance over existing deposits will often erode, bury or remobilise pre-existing accumulations. Therefore, it is the relative position of sediment-landform assemblages within a cirque-valley system, defined in key areas by type sections or type localities, which provides the basis for stratigraphy in mountain areas glaciated by localised ice. For this reason, in glaciated mountain regions at least, integrating morphostratigraphy, previously considered to warrant only informal status (Bowen, 1978), with lithostratigraphy, enables the formalisation of mountain glacial stratigraphy based primarily on landform distribution.

The concept of the morpho-lithostratigraphical unit described above is similar to the allostratigraphical unit which is defined as 'a mappable stratiform body of sedimentary rock that is defined and identified on the basis of its bounding discontinuities' (NASCH, 1983 , p. 865). Miall (1997) argued that allostratigraphical methods enable the erection of a sequence framework that avoids the cumbersome nature of lithostratigraphy, whereby lateral changes in facies within a unit of comparable age require a change in name. In North America, glacial units in mountain areas have been subdivided using allostratigraphy. For example, Dahms (2002) and James et al. (2002) grouped moraines and other glacial features into alloformations. However, Rawson et al. (2002) questioned the necessity of allostrati- graphical units and argued that there appears to be a consensus that if superimposed or contiguous deposits of similar composition can be differentiated by any other method, it is justifiable to classify them as separately named lithostratigraphical units. In glaciated cirque-valley systems, morphostratigraphy is a key criterion in separating similar lithological units and the concept of morpho-lithostratigraphy inherently accommodates lateral changes in facies because of the morphostratigraphical component. In fact, workers such as Dahms (2002) and James et al. (2002) grouped moraines and other glacial features into alloformations based on morphostratigraphical criteria.

Whilst glacial sequences are characterised by erosional hiatuses, it is not the break or discontinuity in a sequence which defines a glacial unit in mountain areas but the sediment-landform assemblage. In other words, mountain glacial deposits are lithological units separable using morphostratigraphical criteria. In fact, in mountain areas, glacial deposits are often tectonised, reworked and homogenised in the vertical profile. Therefore, if a glacier advances over existing deposits, the latter become actively part of a new glacial unit. An example occurs where till becomes deformed below a glacier to form push moraines. Since the final morphology of the deformed unit is the result of processes that acted after deposition of the original material, the pre-existing older sediment must be considered part of the more recent landform. For this reason, vertical discontinuities in glacial sequences in mountain areas are frequently not clear-cut, a condition that undermines any allostratigraphical classification. In mountain areas, morphostratigraphy will always be the defining factor in separating lithological units. It is therefore questionable whether an allostratigraphical approach is strictly appropriate for the classification of mountain glacial sequences.

It is preferable that stratigraphical schemes can be applied to a range of environments. Although the approach outlined in this paper is applied to glacial sediments in mountain regions, it could also be used in the subdivision of periglacial sediments, such as relict rock glaciers and talus deposits, as well as other sedimentary assemblages including debris flow, alluvial fan and landslide deposits. A morpholithostratigraphical approach highlights the importance of landform assemblage as a stratigraphical criterion in certain Quaternary sequences and emphasises its potential for integration into established lithostratigraphical procedure. The latter point is important since it discourages the proliferation of separate stratigraphical or quasi-stratigraphical schemes.

\section{A formal stratigraphical approach - practice}

Sediments and associated landforms can be subdivided using the established universal lithostratigraphical hierarchical terms of Group, Formation, Member and Bed. These basic subdivisons are arbitary units of convenience, so that the application of these terms will depend on the extent of the area under consideration and the nature of the stratigraphical sequence (Matthews, 1984). These terms are therefore applied according to the spatial scale of the research. A stratigraphical approach allows a glacial sequence to be systematically sub-divided and a lithostratigraphical framework to be developed.

\section{Beds}

Beds represent individual sediment units that are considered to have formed during the same depositional event. Bed units are applied in a broad sense so that a stratum of sands and silt, for example, would be classified as one unit. This approach enables closely related glacial and glacio-fluvial deposits to be grouped within a single stratigraphical unit at the member level. In a glaciated valley, a section may comprise the following beds: 
(top of section)

320-400 cm Unit 4: clast-supported diamicton. Angular clasts.

180-320 cm Unit 3: matrix-supported diamicton. Subrounded, striated clasts.

150-180 cm Unit 2: interbedded sand and silts.

$0-150 \mathrm{~cm} \quad$ Unit 1: matrix-supported diamicton. Subrounded, striated clasts.

(base of section)

Where multiple sections are logged, then beds could be subdivided by locality, e.g. Unit a $1,2,3 \ldots$, Unit $b 1,2,3 \ldots$, and so on. It is important to note that the term 'unit' has no stratigraphical significance and is used merely to describe any body of related sediment such as a bed and can be applied at any level of the stratigraphical hierarchy.

\section{Members}

A number of beds in a particular valley may be grouped as part of a member. Sediment units that together constitute a member may be defined from a type section or type locality. Several type sections may be required to fully describe a member, since one exposure may not give a full representation of all the components of the sedimentary sequence. Moreover, at this level, numerical ordering of members is avoided since further intervening units may be discovered in future. For example, two different members at different morphostratigraphical positions in a glaciated valley in the Pindus Moun-

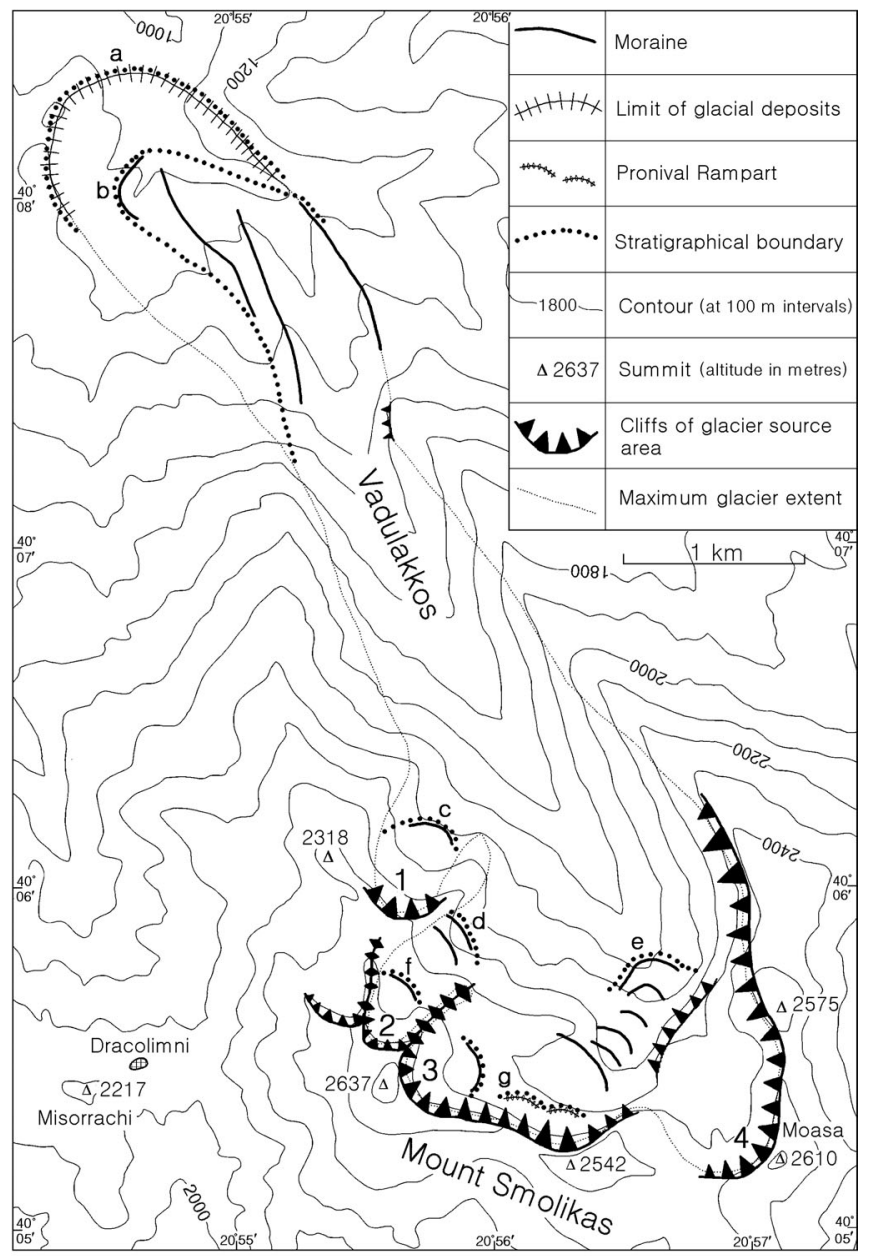

Figure 1 A simplified geomorphological map of a glaciated cirque-valley system on Mount Smolikas, northwest Greece, illustrating the subdivision of morpho-lithostratigraphical units. Cirques are numbered 1 to 4 . A key to the stratigraphical units marked a-g is provided in Table 1 (from Hughes, 2004). tains, Greece, have been termed the Aghia Paraskevi Member and the Vadulakkos Member (Figure 1, Table 1). Names should be based on a geographical locality in the local area, such as a village.

If, as is often the case, the upper valley area is characterised by multiple cirques or tributary valleys, the approach can still be applied. In these circumstances, multiple members can be identified and grouped together in the stratigraphical sequence. For example, in the glaciated valley in the Pindus Mountains shown in Figure 1, moraines at similar altitudes in the tributary cirques all represent part of the same stratigraphical unit (Table 1).

A suite of end moraines and associated recessional moraines may constitute a member in a glaciated valley (Figure 1). Differentiating between suites of moraines deposited during different glacial phases is important so that recessional moraines are not separated stratigraphically from the outermost moraine of a particular glacial phase. If the source of the sediment has remained relatively constant throughout the period concerned, it is possible that the lithological characteristics may not differ significantly between different suites of glacial deposits. Therefore, other criteria, such as the degree of soil development (pedostratigraphy) on moraine surfaces and landform 'freshness' may help to differentiate between surfaces of differing age and both characteristics assist in the establishment of the relative-age of glacial units. However, soil development is arguably the most reliable indicator. Various techniques which quantify the degree of soil development and the relative age of soils are described in Harden (1982), Woodward et al. (1994), van Andel (1998), and Birkeland et al. (2003). Examples of the use of soils and for differentiating between glacial deposits of different glacial stages include papers by Hall and Shroba $(1993,1995)$ and Nelson and Shroba (1998) in the Rocky Mountains of the United States and by Smith et al. (1997) on Mount Olympus in Northeastern Greece.

A down-valley cross-section through a hypothetical glaciated cirque-valley system is shown in Figure 2. This diagram illustrates the use of sediment lithology and landform morphology in conjunction with pedological horizons to subdivide member units. The different glacial and periglacial units are subdivided on the basis of lithology, i.e. diamicton/boulder units, and morphology, i.e. moraine crests and sediment-landform position. The combination of these units to subdivide glacial sequences is termed here, morpho-lithostratigraphy. The subdivision of morpho-lithostratigraphical units is further aided by pedostratigraphy i.e. using soil development characteristics on different surfaces or at buried unit boundaries to determine the relative age of the underlying sediment.

\section{Formations}

The next highest hierarchial division, the formation, would then include all members from a particular cirque-valley system. For example, all the members in the glaciated valley in Greece are together called the North Smolikas Formation (Figure 1, Table 1).

This scheme is rather different to one that could emerge if the glaciers extended to lowland plains and coalesced as part of an ice sheet. In these circumstances, the lowermost stratigraphical glacial unit, traceable over wide areas, would be more suitably classified as a formation with higher, stratigraphically separate units also classified as formations. However, as noted earlier, the application of lithostratigraphical hierarchical terms depends on the extent of the

Table 1 A morpho-lithostratigraphical framework for the Vadulakkos valley on Mount Smolikas, northwest Greece. The different members denoted $a-g$ are indicated in Figure 2 (adapted from Hughes, 2004).

\begin{tabular}{|l|l|c|}
\hline Unit 4 & $\begin{array}{l}\text { g. Smolikas Summit East Member } \\
\text { f. Smolikas Summit North Member }\end{array}$ & \multirow{2}{*}{ NORTH } \\
\cline { 1 - 2 } Unit 3 & $\begin{array}{l}\text { e. } \text { Cirque 3/ Cirque 4 Member } \\
\text { d. } \text { Cirque 2 Member } \\
\text { c. } \text { Cirque1 Member }\end{array}$ & \multirow{2}{*}{ FORMATION } \\
\cline { 1 - 2 } Unit 2 & b. Vadulakkos Member & \\
\hline Unit 1 & a. Aghia Paraskevi Member & \\
\hline
\end{tabular}




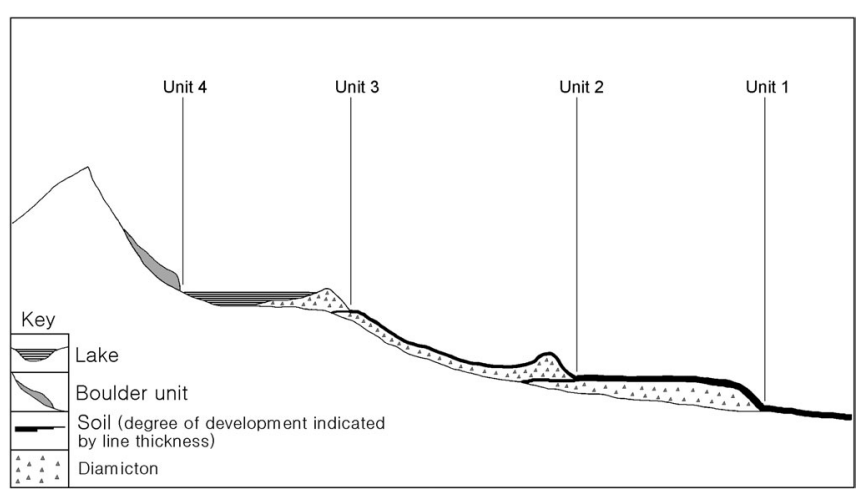

Figure 2 Down-valley cross-section of a hypothetical glaciated cirque-valley system. The diamicton units are glacial in origin and the boulder unit represents a periglacial rock glacier.

area under consideration and is intended as a tool to facilitate systematic understanding of the stratigraphy in a particular area.

\section{Groups}

This would include all the formations of a massif or range of mountains. To prevent over-subdivision, it is preferable to extend the geographical range of the group to whole ranges where suitable. Thus, for example, in the Pindus Mountains of Greece, all the glacial deposits could form part of the Pindus Group (cf. Hughes, 2004) (Table 2). If mountain ranges cover exceptionally large areas characterised by markedly contrasting climates, such as the Andes of South America, then the group could be limited to formations within regions. Another hierarchical term, the Supergroup, could comprise groups of formations over wide areas.

The approach outlined above assumes that in glaciated cirquevalley systems, glacial units will rest on top of each other, separated only by deposits relating to the former units, such as glacio-fluvial or reworked deposits. However, in some sitiuations glacial units may be separated by unrelated sediments. For example, on glaciated volcanic mountains which have been active during the Quaternary, such as in Hawaii, glacial deposits are often separated by lava or tephra

Table 2 An example of the hierarchical approach applied to three valleys on different peaks of the Pindus Mountains, Greece, based on morpho-lithostratratigraphical units and also, in the case of the Tsepelovo Formation, a pedological unit (from Hughes, 2004).

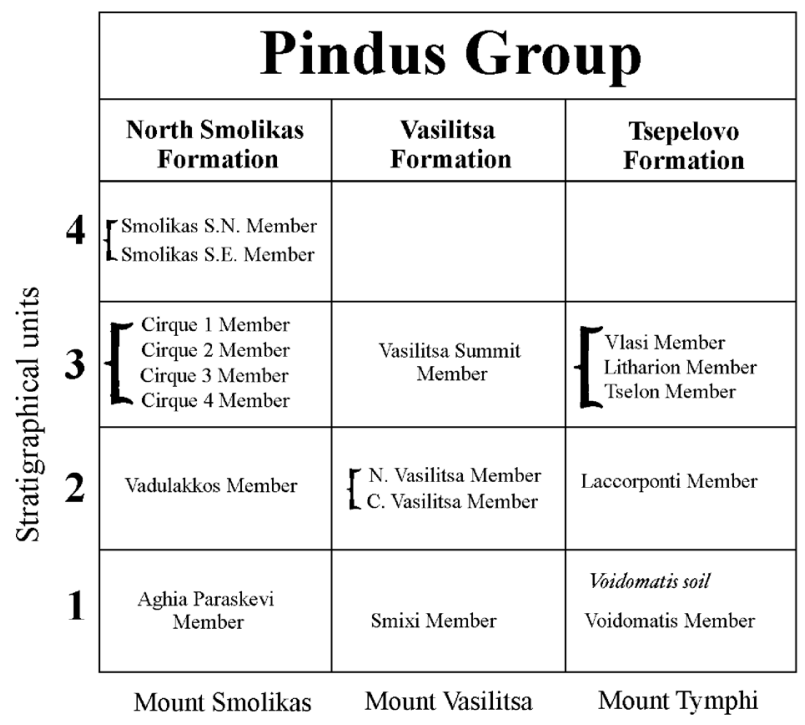

Key

[ Member units of equivalent stratigraphical position in upper tributary valleys/cirques strata (cf. Porter, 1986). In these circumstances, the lava or tephra strata are obviously lithologically separate to the glacial units and therefore each glacial unit would be given the formation status and all of the glacial units in a particular volcanic area would represent a single lithostratigraphical group.

Despite the problems of subdivision encountered in active volcanic areas, the morpho-lithostratigraphical procedure described above is the most logical approach to stratigraphical subdivision and correlation in locally-glaciated areas. However, it does result in the designation of numerous formations at small spatial scales, for instance in every glaciated cirque-valley system. An alternative approach would be to define type sections for inter-valley formations. For example, where they occur in more than one valley, the lowest deposits in a sequence, characterised from a particular stratotype, could be identified as the same formation. If three distinct stratigraphical units occur in all valley systems within a particular region, then three formations, stacked in time one above the other in relative order, would exist in this method of classification. However, in glacial systems, since the glaciers that ultimately formed these deposits are independent of each other, it is questionable as to whether deposits in different valley systems should be viewed as part of the same formation. This is especially the case in marginal glacial environments where local controls potentially exert considerable influence on the local stratigraphy, especially the morphostratigraphical relations of glacial units. Whenever possible, inter-valley correlations should therefore only be attempted once the stratigraphy has been established independently for each separate cirque-valley system. When this is in place, the application of geochronological dating methods is an important next step in correlation between intervalley units in different formations and ultimately for wider comparison with other records.

\section{Making the leap: morpho- lithostratigraphy to chronostratigraphy}

A formal stratigraphical framework is essential for the development of a chronostratigraphy. The stage represents the basic unit of chronostratigraphy and is defined by its boundary stratotypes (type sections), sections that contain a designated point in a stratigraphical sequence. The lower and upper boundary stratotypes of a stage represent specific moments in geological time, and the time interval between them is the time span of the stage. According to Salvador (1994, p. 80), the name of a chronostratigraphical stage should be derived from a geographical feature in the vicinity of its stratotype or type area. In English, the adjectival form of the geographical term is used ending in 'ian' or 'an' (e.g. Elsterian and Eemian in northern Europe). Stage units are defined from well-represented type sections or type localities, especially those where geochronology is also available.

Many Quaternary workers do not see the need for a chronostratigraphically-based system, especially those who rely on geochronological dating methods, such as radiocarbon, for correlation. Critics may therefore argue that an event stratigraphy calibrated by geochronology is the most desirable. However, the use of event stratigraphy to build a terrestrial Quaternary stratigraphy results in a discontinuous stratigraphical framework. This is unsatisfactory, especially since the chronostratigraphical sequence is by its nature continuous and many events may not be recorded across wide areas in the sedimentary record. Even though moraines, particularly individual moraine ridges, often represent 'snapshots' in time (over geological timescales), it is very difficult in practice to ascertain stratigraphical boundaries since glaciers oscillate, readvance and decay over time intervals ranging from decades to thousands of years. This is especially likely during glacial stages since it is well established that climate was unstable with centennial to millennial-scale variability (Dansgaard et al., 1993). Therefore, it is preferable to consider separable glacial units within the chronostratigraphical contin- 
uum and glacier maxima and periods of glacier-front stabilisation as merely events within this continuum.

The problem with terrestrial depositional records will always be one of fragmentation as well as substantially differing rates of sedimentation and erosion in time and space. This makes the concept of chronostratigraphy especially difficult to apply in the context of glaciated mountain environments. This is because it is the lower and upper boundaries between stratigraphical units, representing isochronous surfaces, which define the stage (Bowen, 1978). Defining the base of a unit is often not possible in glaciated mountain areas because glacial units are inherently discontinuous. Moreover, the base of a glacial unit will often be characterised by an erosional contact-a fact utilised by some to apply an allostratigraphical approach, as discussed above. In some instances, a continuous parasequence can be used in conjunction with fragmentary sequences such as the glacial record. For example, glacial and periglacial records in the Pindus Mountains, Greece, dated using U-series on secondary carbonate cements, have been assessed in conjunction with a lacustrine sequence spanning multiple glacialinterglacial cycles at Ioannina (ca. $40 \mathrm{~km}$ to the south), to provide a chronostratigraphy for Greece for approximately the last 500,000 years (Hughes, 2004) (Table 3).

Table 3 Chronostratigraphical table showing the relationship between the fragmentary glacial sequence in the Pindus Mountains, Greece, and the continuous lacustrine parasequence in the nearby Ioannina 249 and 284 cores (Tzedakis, 1994; Tzedakis et al., 2002). The gap in the chronostratigraphical sequence between the Vlasian and Skamnellian Stage is facilitated by the continuous sequence at Ioannina (from Hughes, 2004). Minimum ages for the glacial deposits were obtained, where possible, by $U$-series dating of secondary carbonate cements (Hughes, 2004, Woodward et al., 2004). MIS = Marine Isotope Stage. $\S=$ Names based on Tzedakis et al. (2002) - all other names for the Ioannina sequence are from Tzedakis (1994).

* = Interval dates from Tzedakis et al. (2002) - all other dates from orbitally-tuned marine isotope records (Imbrie et al., 1984; Martinson et al., 1987).

\begin{tabular}{|c|c|c|c|c|c|}
\hline $\begin{array}{l}\text { Age } \\
(x 1,000 \text { years })\end{array}$ & MIS & $\begin{array}{l}\text { Ioannina } \\
\text { (IN 249/284) }\end{array}$ & $\begin{array}{l}\text { Para- } \\
\text { stratotype } \\
\text { boundary } \\
\text { (IN 249) }\end{array}$ & $\begin{array}{l}\text { Pindus } \\
\text { Chrono- } \\
\text { stratigraphy }\end{array}$ & Local Stratotype \\
\hline $11.5-$ & 1 & Holocene & $17.25 \mathrm{~m}$ & & \\
\hline \multirow{3}{*}{$73.9-11.5$} & 2 & & \multirow[b]{7}{*}{$45.88 \mathrm{~m}$} & \multirow{7}{*}{ Tymphian } & \multirow{7}{*}{$\begin{array}{l}\text { Tsouka Rossa Member } \\
39^{\circ} 58^{\prime} 45^{\prime \prime} \mathrm{N}, 20^{\circ} 50^{\prime} 40^{\prime \prime} \mathrm{E}, 2025 \text { m a.s.l. }\end{array}$} \\
\hline & 3 & & & & \\
\hline & 4 & & & & \\
\hline $73.9-83.0^{*}$ & $5 a$ & Interstadial $2^{\S}$ & & & \\
\hline $88.5 *-83.0^{*}$ & $5 b$ & Stadial $2^{\S}$ & & & \\
\hline $104.5^{*}-88.5^{*}$ & $5 c$ & Interstadial $1^{\S}$ & & & \\
\hline $111.0^{*}-104.5 *$ & $5 d$ & Stadial $1^{\S}$ & & & \\
\hline $126.6^{*}-111.0^{*}$ & $5 e$ & Metsovon & $59.00 \mathrm{~m}$ & & \\
\hline $189.6-126.6 *$ & 6 & & $76.00 \mathrm{~m}$ & $\begin{array}{l}\text { Vlasian } \\
\text { Stage }\end{array}$ & $\begin{array}{l}\text { Vourtapa Member } \\
39^{\circ} 55^{\prime} 50^{\circ} \mathrm{N}, 20^{\circ} 51^{\prime} 10^{\circ 1} \mathrm{E}, 1650 \mathrm{~m} \text { a.s. } .\end{array}$ \\
\hline $244.2-189.9$ & $7 a-e$ & $\begin{array}{l}\text { IN-26 } \\
\text { Zitsa } \\
\text { IN-23a }\end{array}$ & & \multirow{4}{*}{$?$} & \\
\hline $303-244.2$ & 8 & & & & \\
\hline $339-303$ & $9 a-e$ & \begin{tabular}{|l|} 
Katara \\
IN-17 \\
Pamvotis
\end{tabular} & & & \\
\hline $362-339$ & 10 & & & & \\
\hline $423-362$ & 11 & Dodoni I/ II & $162.75 \mathrm{~m}$ & & \\
\hline $478-423$ & 12 & & $184.00 \mathrm{~m}$ & $\begin{array}{c}\text { Skamnellian } \\
\text { Stage }\end{array}$ & $\begin{array}{l}\text { Kato Radza Member } \\
39^{\circ} 54^{\prime} 08^{\prime \prime} \mathrm{N}, 20^{\circ} 50^{\prime} 40^{\prime \prime} \mathrm{E} .984 \mathrm{~m} \text { a.s.l. }\end{array}$ \\
\hline
\end{tabular}

\section{Conclusions}

It is proposed that investigations of glacial deposits in mountain areas should follow a formal stratigraphical approach. In mountain regions, glacial deposits can be subdivided using a standard lithostratigraphical hierarchical structure utilising both litho- and morphostratigraphical criteria. A morpho-lithostratigraphical approach is advocated here in preference to allostratigraphy since the latter is unsuited to the subdivision of glacial deposits in cirque-valley systems. Other criteria, such as pedological development, can also be useful in recognising surfaces of different age and should be used alongside morpho-lithostratigraphical procedure where possible. Ultimately, geochronological techniques can be applied to support inter-valley correlation and to determine the position of sedimentary units in time.

The integration of Quaternary glacial records, and indeed any Quaternary record, into formal stratigraphy, should facilitate changes and revisions that new evidence may bring, and thus contribute to a robust stratigraphical framework. Furthermore, established geomorphological approaches commonly used in glaciated mountain areas need to be integrated within a formal stratigraphy if we are to better understand the impact of environmental change across the 
Earth's surface. This is preferable to the common approach in glaciated mountain regions, whereby sequences are ordered in time through direct reference to the marine isotope record of global ice volume, before local and regional stratigraphical frameworks are established. These frameworks are essential for the development of integrated terrestrial stratigraphies, including those in glaciated mountain regions, and should be a prerequisite before comparison and attempted correlation with the isotope records.

\section{Acknowledgements}

PDH was funded by a University of Cambridge Domestic Research Studentship (2001-2004) and a University of Manchester Faculty of Humanities Fellowship (2004-2006). We thank Professor Mike Hambrey for helpful comments on an initial version of this manuscript.

\section{References}

Benn, D.I. and Evans, D.J.A. 1998, Glaciers and Glaciation. Arnold: London. Birkeland, P.W., Shroba, R.R., Burns, S.F., Price, A.B. and Tonkin, P.J. 2003, Integrating soils and geomorphology in mountains - an example from the Front Range of Colorado. Geomorphology 55, 329-344.

Björk, S., Walker, M.J.C., Swynar, L.C., Johnsen, S. Knudsen, K.L., Lowe, J.J., Wohlfarth, B. and INTIMATE Members 1998, An event stratigraphy for the Last Termination in the North Atlantic Region based on the Greenland ice-core record-a proposal of the INTIMATE group. Journal of Quaternary Science 13, 283-292.

Bowen, D.Q. 1978, Quaternary Geology: A Stratigraphic Framework for Multidisciplinary Work. Pergamon: Oxford.

Clapperton, C.M., Sugden, D.E., McCulloch, R.D. and Kaufmann, D.S. 1995, The last glaciation in the Magellan Strait. Quaternary Research 44, 133-148.

Dahms, D.E. 2002, Glacial stratigraphy of Stough Creek Basin, Wind River Range, Wyoming. Geomorphology 42, 59-83.

Dansgaard, W., Johnsen, S.J., Clausen, H.B., Dahl-Jensen, D., Gundestrup, N.S., Hammer, C.U., Hvidberg, C.S., Steffensen, J.P., Sveinbjörnsdottir, A.E., Jouzel, J. and Bond, G. 1993, Evidence for general instability of past climate from a 250 year ice core record. Nature 364, 218-220.

Ehlers, J. \& Gibbard, P.L. eds, 2004a, Quaternary Glaciations - Extent and Chronology, Part I: Europe . Developments in Quaternary Science, Vol. 2a. Elsevier: Amsterdam.

Ehlers, J. \& Gibbard, P.L. eds, 2004b, Quaternary Glaciations - Extent and Chronology, Part II: North America. Developments in Quaternary Science, Vol. 2b. Elsevier: Amsterdam.

Ehlers, J. \& Gibbard, P.L. eds, 2004c, Quaternary Glaciations - Extent and Chronology, Part III: South America, Asia, Africa, Australasia, Antarctica. Developments in Quaternary Science, Vol. 2c. Elsevier: Amsterdam.

García-Ruiz, J.M., Valero-Garcés, B.L., Martí-Bono, C. and González-Sampériz, P. 2003: Asynchroneity of maximum glacier advances in the central Spanish Pyrenees. Journal of Quaternary Science 18, 61-72.

Gibbard, P.L. and West, R.G. 2000, Quaternary chronostratigraphy: the nomenclature of terrestrial sequences. Boreas 29, 329-336.

Hall, R.D. and Shroba, R.R. 1993, Soils developed in the glacial deposits of the type areas of the Pinedale and Bull Lake Glaciations, Wind River Range, Wyoming, USA. Arctic and Alpine Research 25, 368-373.

Hall, R.D. and Shroba, R.R. 1995 Soil evidence for a glaciation intermediate between the Bull Lake and Pinedale Glaciations at Fremont Lake, Wind River Range, Wyoming, USA. Arctic and Alpine Research 27, 89-98.

Harden, J.W. 1982, A quantitative index of soil development from field descriptions: examples from a chronosequence in central California. Geoderma 28, 1-28.

Hedberg, H.E. 1976, International stratigraphic guide: a guide to stratigraphic classification, terminology and procedure. International Subcommission on Stratigraphic Classification of IUGS commission on Stratigraphy. Wiley: Chichester. $200 \mathrm{pp}$.

Hughes, P.D. 2004, Quaternary Glaciation in the Pindus Mountains, Northwest Greece. Ph.D. thesis, University of Cambridge. 341 pp.

Imbrie, J., Hays, J.D., Martinson, D.G., McIntyre, A., Mix, A.C., Morley, J.J., Pisias, N.G., Prell, W.L. and Shackleton, N.J. 1984, The orbital theory of Pleistocene climate: support from a revised chronology of the marine 180 record. In Berger, A., Imbrie, J., Hays, G. Kukla, G. and
Saltzman, B. eds, Milankovitch and Climate. Reidel: Dortrecht. p. 269306.

Imbrie, J., Berger, A. and Shackleton, N.J. (1993) Role of orbital forcing: a two-million-year perspective. In Eddy, J.A. and Oeschger, H. (eds) Global Changes in the Perspective of the Past. Wiley: Chichester. p. 263277.

International Commission on Stratigraphy 2004, International Stratigraphic Guide. http://www.stratigraphy.org/

Jalut, G., Montserrat, J., Fontunge, M., Delibrias, G., Vilaplana, J. and Juli-, R. 1992, Glacial to interglacial vegetation changes in the northern and southern Pyrenees: deglaciation, vegetation cover and chronology. Quaternary Science Reviews 11, 449-480.

James, L.A., Harbor, J., Fabel, D., Dahms, D. And Elmore, D. 2002, Late Pleistocene glaciations in the northwestern Sierra Nevada, California. Quaternary Research 57, 409-419.

Lowe, J.J. and Walker, M.J.C. 1997, Reconstructing Quaternary Environments. 2nd Edition. Longman.

Martinson, D.G., Pisias, N.G., Hays, J.D., Imbrie, J., Moore, T.C. and Shackleton, N.J. 1987, Age dating and the orbital theory of the ice ages: development of a high resolution 0-300,000 year chronostratigraphy. Quaternary Research 27, 1-29.

Matthews, R.K. 1984, Dynamic Stratigraphy : An Introduction to Sedimentation and Stratigraphy. 2nd Edition. Prentice-Hall: London.

Miall, A.D. 1997, The Geology of Stratigraphic Sequences. Springer-Verlag: Berlin.

Nelson, A.R. and Shroba, R.R. 1998, Soil relative dating of moraine and outwash-terrace sequences in the northern part of the upper Arkansas Valley, central Colorado, USA

Arctic and Alpine Research 30, 349-361.

North American Commission on Stratigraphic Nomenclature 1983, North American stratigraphic code. American Association of Petroleum Geologists, Bulletin 67, 841-875

Osmaston, H.A. 1989a, Problems of the Quaternary geomorphology of the Xixabangma region in south Tibet and Nepal. Zeitschrift für Geomorphologie 76, 147-180.

Osmaston, H.A. 1989b, Glaciers, glaciations and equilibrium line altitudes on the Ruwenzori. in Mahaney, W.C. ed, Quaternary and Environmental Research on East African Mountains. Balkema: Rotterdam. p. 7-30.

Osmaston, H.A. 2002, Chapter 9. The nature, extents and climates of former Quaternary tropical glaciers, with reference to the East African Mountains. in Kaser, G. and Osmaston, H. eds, Tropical Glaciers. Cambridge University Press: Cambridge. p. 149-192.

Owen, L.A., Derbyshire, E. and Fort, M. 1998, The Quaternary Glacial history of the Himalaya. Quaternary Proceedings 6, 91-120.

Porter, S.C. 1986, Glaciation of Mauna-Kea, Hawaii. Quaternary Science Reviews 5, 181-182.

Rawson, P.F., Allen, P.M., Brenchley, P.J., Cope, J.C.W., Gale, A.S., Evans, J.A., Gibbard, P.L., Gregory, F.J., Hailwood, E.A., Hesselbo, S.P., Knox, R.W.O'B., Marshall, J.E.A., Oates, M., Riley, N.J., Smith, A.G., Trewin, N., Zalasiewicz, J.A. 2002, Stratigraphical Procedure. The Geological Society: London.

Richmond, G.M. 1959, Report of the Pleistocene committee, American Commission on stratigraphic nomenclature. American Association of Petroleum Geologists, Bulletin 43, 633-675.

Richmond, G.M. and Fullerton, D.S. 1986, Introduction to Quaternary glaciations in the United States of America. Quaternary Science Reviews 5,3-10.

Salvador, A. ed, 1994, International Stratigraphic Guide: A Guide to Stratigraphic Classification, Terminology and Procedure. 2nd Edition. International Union of Geological Sciences and The Geological Society of America: Boulder, Colorado.

Seret, G., Dricot, J. and Wansard, G. 1990, Evidence for an early glacial maximum in the French Vosges during the last glacial cycle. Nature 346, $453-$ 456

Shackleton, N.J., Berger, A. and Peltier, W.R. 1990, An alternative astronomical calibration of the lower Pleistocene timescale based on ODP Site 677. Transactions of the Royal Society of Edinburgh: Earth Sciences 81, 251-261

Shanahan, T.M. and Zreda, M. 2000, Chronology of Quaternary glaciations in East Africa. Earth and Planetary Science Letters 177, 23-42.

Smith, G.W., Nance, R.D. and Genes, A.N. 1997, Quaternary Glacial History of Mount Olympus, Greece. Geological Society of America Bulletin 109, 809-824.

Tzedakis, P.C. 1994, Vegetation change through glacial-interglacial cycles: a long pollen sequence perspective. Philosophical Transactions of the Royal Society of London B345, 403-432. 
Tzedakis P.C., Lawson I.T., Frogley M.R., Hewitt G.M., Preece R.C. 2002, Buffered tree population changes in a Quaternary refugium: evolutionary implications. Science 297, 2044-2047.

van Andel, T.H. 1998, Paleosols, red sediments, and the Old Stone Age in Greece. Geoarchaeology: An International Journal 13, 361-390.

Whittaker, A., Cope, J.C.W., Cowie, J.W., Gibbons, W., Hailwood, E.A., House, M.R., Jenkins, D.G., Rawson, P.F., Rushton, A.W.A, Smith, D.G., Thomas, A.T. and Wimbledon, W.A. 1991, A guide to stratigraphical procedure. Journal of the Geological Society, London 148, 813-824.

Woodward, J.C., Macklin, M.G. and Lewin, J. 1994, Pedogenic weathering and relative-age dating of Quaternary alluvial sediments in the Pindus Mountains of northwest Greece. In Robinson, D.A. and Williams, R.B.G. eds, Rock Weathering and Landform Evolution. Wiley.

Woodward, J.C., Macklin, M.G. and Smith, G.R. 2004, Pleistocene Glaciation in the Mountains of Greece. in Ehlers, J. and Gibbard, P.L., eds, Quaternary Glaciations - Extent and Chronology. Part I: Europe. Elsevier: Amsterdam. p. 155-173.

Phil Hughes obtained his Ph.D. at the Department of Geography, University of Cambridge, England, in 2004, working on Quaternary glaciation in the Pindus Mountains, Northwest Greece. In September 2004, he was appointed to the position of Postdoctoral Fellow in Geography, at the School of Environment and Development in the Faculty of Humanities at The University of Manchester, working on the glacial and periglacial history of the Mediterranean region.
Phil Gibbard is Reader in Quaternary Palaeoenvironments at the University of Cambridge, United Kingdom, and chair of the International Commission on Stratigraphy's Subcommission on Quaternary Stratigraphy. He is also a member, and was formally Secretary, of the Stratigraphy and Geochronology Commission of INQUA, the INQUA Subcommission of European Quaternary Stratigraphy and the Geological Society of London's Stratigraphy Commission. His research is focused on terrestrial and shallow marine sedimentation, stratigraphy and environmental evolution throughout Europe, but he has also worked in the Arctic, North America and South-East Asia.

\begin{abstract}
Jamie Woodward is Reader in Physical Geography in the School of Environment and Development at University of Manchester. He has published widely on Quaternary environmental change, geomorphology and geoarchaeology in the Mediterranean region and the Nile Valley. He is the specialist subject editor for Quaternary Science and Geomorphology for the Journal of the Geological Society and is a member of the editorial board of Geoarchaeology: An International Journal. His research is focused on the response of fluvial systems to environmental change, palaeoenvironmental significance of sedimentary records in caves and rockshelters, and development of geochronologies for these environments.
\end{abstract}
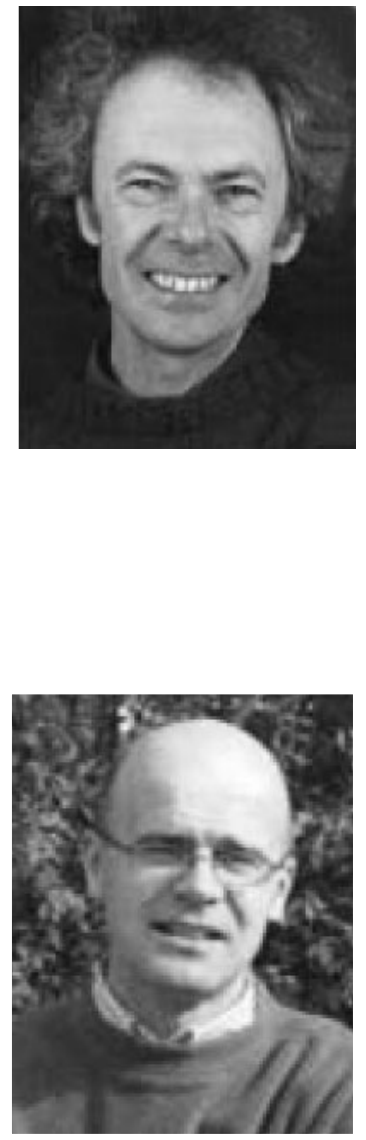

\title{
CALL FOR PAPERS
}

Episodes is the quarterly science and news journal of the International Union of Geological Sciences (IUGS). It focuses on the publication of results of scientific research and other information addressing issues of interest to the global earth-science community. Special emphasis is given to topics involving geological aspects of population growth and economic development and their resulting impacts on or implications for society. As the principal publication of the IUGS, Episodes also carries information about IUGS scientific programs and activities to the extent necessary to communicate effectively with the worldwide IUGS constituency.

Contributions of the following types of manuscripts are here solicited:

- scientific articles

- conference reports

- news and views

- letters to editor

- book reviews

- information on training courses (especially those geared to participants from developing countries)

- noteworthy new publications, including national or regional geologic maps

Episodes also invites photos or other images for the front cover. Photos must be of high technical quality and tell an interesting geological story. A color transparency and one color print (at least $9 \mathrm{~cm} \times 12.6 \mathrm{~cm}$ ) are required for submission, which should be supplemented with a short explanatory paragraph (no more than 100 words).

Please address all contributions to:

\author{
The Editor \\ Episodes \\ P. O. Box 823, 26 Baiwanzhuang Road \\ 100037 Beijing, CHINA \\ Tel: +86-10-68320827, +86-10-68329084 \\ Fax: +86-10-68328928 \\ E-mail: episodes88@yahoo.com
}

